\title{
Non-Farm Enterprises and Poverty Reduction amongst Households in Rural Nigeria: A Propensity Score Matching Approach
}

\author{
${ }^{1,2}$ Abdulaziz Shehu, ${ }^{1}$ Shaufique Fahmi Bin Ahmad Siddique \\ ${ }^{l}$ Faculty of Economics and Management, University Putra Malaysia \\ ${ }^{2}$ Sokoto State Polytechnic, Nigeria
}

\begin{abstract}
The data of nationally representative household survey from rural Nigeria was used to examine the effect of non-farm enterprise activities on improvement in the welfare of households in rural Nigeria, using total annual household consumption expenditure as a measure of their welfare. Propensity score matching approach was used for the analysis, and the result shows that rural households that engage in non-farm enterprise activities are having higher consumption expenditure than those that did not diversify into such activities. This suggests that, non-farm enterprises could be a pathway for improving the wellbeing of rural households in Nigeria and in the remaining sub-Saharan African countries.
\end{abstract}

Key Words: Non-farm enterprises; Poverty, Household wellbeing, Rural Nigeria, Propensity Score Matching

\section{Introduction}

The development of non-farm enterprises (NFEs) has been given much attention in developing countries as a result of its significant contribution in improving household wellbeing. The non-farm enterprise activities reduces the rate of rural-urban migration by providing job opportunities to growing rural labor force that cannot be employed in the agricultural sector, and it also supplements agricultural earning. Likewise, nonfarm activities may enhance income growth and promote a more equitable distribution of income among the rural households [1-3]. Evidences from developing countries suggest that the sector accounts for 30-45 percent of rural households' income [1,4]

Despite the potential role of non-farm enterprises in improving houseld wellbeing in developing countries, studies on rural development have not given much attention to its contribution to household economic wellbeing $[3,5]$, which makes it difficult to assess its impact on wellbeing of rural households. Most existing studies in the literature focus on the effect of non-farm wage employment on household wellbeing $[6,7,8]$.

To contribute to the literature, this study uses a nationally representative sample data of 3380 rural households from Nigeria to examine the impact of non-farm enterprise activities on improvement in the wellbeing of rural households in the country, using annual household consumption expenditure as indicator of household wellbeing. The study uses propensity score matching technique for its analysis, which takes care of self-selection bias that exists in the sample by matching enterprise and non-enterprise rural households that share the same pre-treatment characteristics [9].

The rest of the paper is organized as follows. The next section presents the literature review. Section three discusses the methodology used in collecting and analysing the data used for this study. Section four discusses the empirical findings and Section five concludes.

\section{Literature Review}

This paper sees non-farm enterprises as all forms of non-farm businesses that are carried out in the nonfarm sector of the economy. Such activities include trading, manufacturing, mining and all other forms of human services. The recent literature on the relevance of the non-farm sector to household wellbeing in developing countries tends to suggest mixed effects. [3] argue that, some rural households may be pushed into non-farm enterprise activities in their struggle to survive, while others may be pulled into such activities by their desire to accumulate wealth. The push factors are usually associated with the poor, and the pull factors are more likely associated with the non-poor households. [2] supports this argument and urged that, household participation in non-farm activities may be associated with success at achieving livelihood security under improved economic conditions, as well as overcoming livelihood distress under deteriorating conditions. In a review of 18 field studies, [10] revealed that the share of non-farm income in total income of the poorer households is higher than that of higher income households. The study carried out in Asia comprising of Japan, Taiwan and South Korea revealed that the poorer/landless households have made a higher percentage of their 
Non-Farm Enterprises And Poverty Reduction amongst households In Rural Nigeria: A Propensity Score Matching...

income from non-farm activities, which suggest that the non-farm sector has a positive impact on poverty reduction in the region [3]

In the case of Burkina Faso [1], employ a recursive system to examine the interaction between nonfarm diversification, household income and consumption expenditure, the result shows that non-farm diversification has a positive impact on the income and food consumption expenditure of the households. [11] uses propensity score matching approach to examine the welfare impact of non-farm diversification in rural Rwanda by comparing the earnings of an enterprise and non-enterprise households. Their result shows that the enterprise households are better off than non-enterprise households in terms of their wellbeing. In the same vein [8] used propensity score matching approach to assess the impact of non-farm work on the food security status and household income in northern Ghana; they revealed that non-farm work has a positive impact on income and food security status of the households. Similarly, [12] also used propensity score matching approach to examine the impact of non-farm enterprise diversification on household wellbeing in Ethiopia using income and food security status of the household as indicators of their wellbeing, the result shows that non-farm enterprise diversification has a positive significant impact on household wellbeing by all measures.

\section{Estimation Procedure}

\section{Methodology}

Propensity score matching approach was used to examine the impact non-farm enterprise activities on the wellbeing of farm households in rural Nigeria. The method compares the welfare of farm enterprise households with their counterfactual group that did not diversify into such activities using consumption expenditure as a measure of their welfare. The propensity score $P\left(T_{i}\right)$ is defined as the conditional probability of receiving a treatment given pre-treatment characteristics:

$P\left(T_{\mathrm{i}}\right) \equiv \operatorname{prob}\left(D_{\mathrm{i}}=1 \mid T_{\mathrm{i}}\right)=E\left(D_{\mathrm{i}} \mid T_{\mathrm{i}}\right) ; P\left(T_{\mathrm{i}}\right)=F\left(h\left(T_{\mathrm{i}}\right)(1)\right.$

Where $T_{i}$ denotes a vector of pre-treatment characteristics of household $i_{*}^{*} E$ is the expectation operator; and $F($ ) represents normal or logistic cumulative distribution frequency.

The propensity scores are predicted with probit model [13]. The assumption of the conditional independence of the score result extends the use of the propensity scores for the computation of the conditional treatment effect. The predicted propensity scores are used to measure the treatment effect.

According to [14], average treatment effect on the treated (ATT) is the parameter of interest in propensity score matching analysis. Thus, we use ATT to assess the effects of participation on household wellbeing. ATT is computed by matching enterprise and non-enterprise households that are closest in terms of their propensity scores. In this study, the treated group are referred to as enterprise households and the ATT is calculated as follows:

$$
A T T=E(T \mid 1=1)=E(Y(1) \mid D=1)-E(Y(0) \mid D=1)(2)
$$

Where $E(Y(1) \mid D=1)$ represents the expected welfare outcome of enterprise households and $E(Y(0) \| D=1)$ denotes the counterfactual welfare of non-enterprise households. The counterfactual estimates represent what the welfare outcome of enterprise households would be, if they have not engaged in non-farm enterprise activities.

A number of matching techniques have been suggested in the literature to match enterprise and nonenterprise households of similar propensity scores to compute the ATT. However, this study employs a radius matching technique, which uses all of the comparison units within a pre-determined radius. The advantage of this method is that it uses as many comparison units available within the radius, thus allowing for the use of extra units when good matches are not available.

\section{Data and Measurement of Variables}

The data for this study is obtained from the general household survey of 3380 rural households undertaken by the Nigerian Bureau of Statistics in collaboration with the World Bank in 2011. The survey is designed in accordance to World Bank Living Standards Measurement Surveys (LSMS), and it used a comprehensive list of all the enumeration areas in Nigeria, together with their respective population as its sampling frame. A two-stage stratified random sampling design was used for sample selection. In the first stage, 500 enumeration areas were selected in proportional to the size of the total enumeration areas in each of the states and also the Federal Capital Abuja. While in the second stage, 10 households were randomly selected from each enumeration area giving a total of 5,000 targeted households. Out of the targeted respondents, only 97.02\% completed the survey with 3380 and 1471 households from rural and urban areas respectively. The survey covered detailed information on non-farm enterprise activities of the households, household consumption expenditure and all other aspects of household living conditions [14].

Household wellbeing is measured by the total annual consumption expenditure of the household. The household consumption expenditure includes the total annual expenditure for all goods and services consumed 
Non-Farm Enterprises And Poverty Reduction amongst households In Rural Nigeria: A Propensity Score Matching... by the household, which entails the monetary value all the goods and services that are produced by the household for household consumption.

The observable variables explaining the characteristics of the households are used to measure the predicted propensity scores. The variables are grouped under individual household characteristics, household endowments, community level characteristics and entry barriers. The variables representing individual household characteristics in the model include gender, age, and educational attainment of household head. Household endowments are explained by land and family size of the household. Community level characteristics are captured by access to electricity, public transportation, proximity to market and location. While entry barriers are captured by access to social capital and credit facilities.

Table 1: Definition of Variables

\begin{tabular}{|l|l|l|}
\hline Variable Name & Measure & \\
\hline Dependent Variables & & Definition \\
\hline Consumption expenditure & Continuous & Total annual household consumption expenditure \\
\hline Household Characteristics & & \\
\hline Gender & Dummy & 1 if household head is male, 0 otherwise \\
\hline Age & Continuous & Years of household head \\
\hline Age Square & Continuous & Square of years of household head \\
\hline Education & Continuous & Years of schooling of household head \\
\hline Household Endowments & & \\
\hline Household Size & Continuous & Number of household members \\
\hline Land Size & Continuous & Size of household land in hectares \\
\hline Community Characteristics & & \\
\hline Electricity & Dummy & 1 if household has access to electricity, 0 otherwise \\
\hline Transportation & Dummy & 1 if household has access to public transportation, 0 otherwise \\
\hline Market & Continuous & Proximity of household to market in kilometres \\
\hline Region & Dummy & 1 if household resides in southern Nigeria, 0 otherwise \\
\hline Entry Barriers & & \\
\hline Social Capital & Dummy & $\begin{array}{l}1 \text { if household head is a member of any association, } 0 \\
\text { otherwise }\end{array}$ \\
\hline Credit & & 1 if household has access to credit, 0 otherwise \\
\hline
\end{tabular}

\section{Findings}

The matching of enterprise and non-enterprise households was undertaken within a region of common support in order to ensure that individual households with the same covariates have equal chances of diversifying into non-farm enterprise activities [13]. This takes care of possible selection bias in the sample by matching of households with similar characteristics from the two groups before computing the wellbeing effects.

A test of the balancing property was also conducted and the results show that matching property was satisfied. This implies that the distribution of the conditioning covariates did not differ across the treatment and comparison group in the matched samples. The results of the balancing property test for the propensity score matching analysis are presented in Table Column I and II of Table 1 indicate the results of the chi-square test for joint significance of the covariates used in the probit model before and after the match. The chi-square test after the match shows that the probability value all the covariates in the probit model are not jointly significant. This confirms that there are no pre-treatment differences between the enterprise and non-enterprise households; meaning that the self-selection bias has been removed, satisfying the matching requirement for computing treatment effects

Table 2: Balancing Property for Propensity Score Matching Analysis

\begin{tabular}{rrrrrr}
\hline I & II & III & IV & V \\
\hline
\end{tabular}


Non-Farm Enterprises And Poverty Reduction amongst households In Rural Nigeria: A Propensity Score Matching...

\begin{tabular}{|c|c|c|c|c|c|}
\hline Independent Variable & $\begin{array}{l}\text { p-value }{ }^{\mathrm{a}} \\
\text { (Unmatched ) }\end{array}$ & $\begin{array}{l}\text {-value } \\
\text { (matched) }\end{array}$ & $\begin{array}{l}\text { Mean }^{\mathrm{b}} \\
\text { absolute } \\
\text { bias } \\
\text { (Unmatched) }\end{array}$ & $\begin{array}{l}\text { Mean }^{\mathrm{b}} \\
\text { absolute } \\
\text { bias } \\
\text { (matched) }\end{array}$ & $\begin{array}{l}\text { Absolute } \\
\text { bias } \\
\text { reduction }\end{array}$ \\
\hline \multicolumn{6}{|c|}{ Household Characteristics } \\
\hline Gender & 0.01 & 0.42 & 0.89 & 0.19 & 78.8 \\
\hline Age & 0.01 & 0.60 & 48.0 & 6.09 & 87.3 \\
\hline Age Square & 0.01 & 0.64 & 2596 & 244 & 90.6 \\
\hline Education & 0.01 & 0.84 & 4.66 & 0.26 & 94.4 \\
\hline Education Square & 0.02 & 0.70 & 51.9 & 0.45 & 82.4 \\
\hline \multicolumn{6}{|l|}{ Household Endowments } \\
\hline Household Size & 0.01 & 0.56 & 6.26 & 0.45 & 92.7 \\
\hline Land Size & 0.01 & 0.45 & 2.05 & 0.62 & 85.5 \\
\hline \multicolumn{6}{|c|}{ Community Characteristics } \\
\hline Electricity & 0.01 & 0.77 & 0.22 & 0.08 & 77.5 \\
\hline Transportation & 0.14 & 0.83 & 0.57 & 0.08 & 85.2 \\
\hline Market & 0.01 & 0.90 & 3.30 & 0.03 & 98.8 \\
\hline Region & 0.01 & 0.91 & 0.63 & 0.01 & 98.0 \\
\hline \multicolumn{6}{|l|}{ Entry Barriers } \\
\hline$\overline{\text { Social Capital }}$ & 0.01 & 0.38 & 0.24 & 0.03 & 84.9 \\
\hline Credit & 0.07 & 0.57 & 0.27 & 0.08 & 67.5 \\
\hline
\end{tabular}

Note: ${ }^{\mathrm{p}} \mathrm{p}$-value of likelihood ratio test $\left(\operatorname{Pr}>x^{2}\right)$

Radius matching is used in this study to quantify the impact of households' participation in non-farm enterprise activities on their wellbeing. The radius matching results presented in Table 2 indicates that nonfarm enterprises have a positive and significant impact on consumption expenditure of the households. Specifically, the estimates of the average treatment effect show that households that engage in non-farm enterprises have on average, more annual consumption expenditure of $\$ 78,716$ (\$524) than those who have not engage into nonfarm enterprise activities, depending on only farm activity.. This result is in line with the finding of [12] who used a similar approach to investigate the effect of participation in non-farm enterprise activities on farm household's wellbeing in Ethiopia.

Table 3: Treatment Effects

\begin{tabular}{|c|c|c|c|c|c|c|}
\hline Radius Matching & & & Treated & & Control & \\
\hline Treatment & Outcome indicators & ATT & $\begin{array}{c}\text { On } \\
\text { Support }\end{array}$ & $\begin{array}{l}\text { Off } \\
\text { Support }\end{array}$ & $\begin{array}{l}\text { On } \\
\text { Support }\end{array}$ & $\begin{array}{l}\text { Off } \\
\text { Support }\end{array}$ \\
\hline $\begin{array}{l}\text { Participation } \\
\text { In NFE activity }\end{array}$ & Consumption Expenditure & $\begin{array}{l}78716^{\text {**** }} \\
(7491)\end{array}$ & 1,579 & - & 1,676 & - \\
\hline
\end{tabular}

Note: Standard errors are reported in parenthesis

Household consumption expenditure is in Naira.

Exchange rate as at 2011 is US $\$ 1=N 150$

$*, * *, * * *$ represents $10 \%, 5 \%$ and $1 \%$ significance levels respectivelyl

Sensitivity analysis is performed by using Nearest Neighbour and Kernel Gaussian matching techniques to check if our radius matching results are robust to other matching methods. The results of the two methods presented in Table 3 confirm that our radius matching result method are quite robust and are not sensitive to other matching techniques. This implies that although our radius matching estimates of the wellbeing effects are consistent with other methods but the radius outcome is slightly higher than that of other techniques.

Table 4: Sensitivity of Matching Algorithms

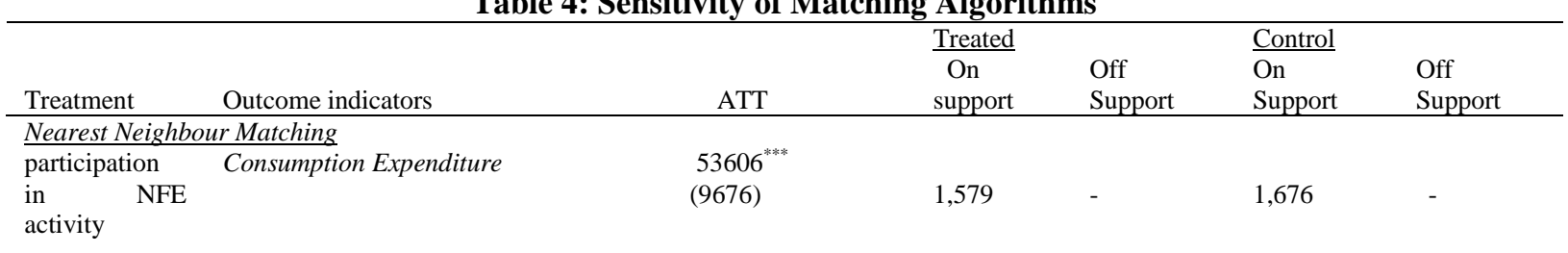


Non-Farm Enterprises And Poverty Reduction amongst households In Rural Nigeria: A Propensity Score Matching...

\begin{tabular}{llccc}
\hline Kernel Gaussian matching & & & \\
Participation Consumption Expenditure & $30089^{* *}$ & 1,576 & 3 & 1,676 \\
in NFE & $(5640)$ & & - \\
activity & & & \\
\hline
\end{tabular}

Note: Standard errors are reported in parenthesis

Household consumption expenditure is in Naira.

Exchange rate as at 2011 is US $\$ 1=\$ 150$

$*, * *, * * *$ represents $10 \%, 5 \%$ and $1 \%$ significance levels respectively

\section{Conclusion}

This study employs propensity matching technique to examine the impact of non-farm enterprise activities on the wellbeing of households in rural Nigeria, using nationally representative survey data of rural households in the country. The poverty status of the households was measured by using total annual consumption expenditure of the household as wellbeing indicator. The matching result shows that the consumption expenditure of rural households that diversify into non-farm enterprise activities is higher than that of households that did not diversify into non-farm enterprise activities in rural Nigeria. This finding is consistent with the widely held view in the literature that income from non-farm enterprise activities plays a vital role to smoothen household consumption, which in turn improves household wellbeing.

The findings of this study strongly suggest that non-farm enterprise activities could be a pathway for improvement in the wellbeing of rural households in Nigeria. Therefore, the policymakers should promote households participation in non-farm enterprise activities by providing adequate infrastructure and formal credit facilities needed by the households. However, further research is still needed to find out whether it is the poor or the non- poor that are benefiting from non-farm enterprise activities in rural Nigeria.

\section{Acknowledgement}

The researchers thank the Nigerian Bureau of Statistics for giving us the permission to use its data for this research.

\section{References}

[1]. Reardon, T.; Delgado, TC and Malton, P. (1992). Determinants and effects of income diversification among farm households in Burkina Faso. Journal of Development, 289(2), 264-296.

[2]. Ellis, F. (2000). The Determinants of Rural Livelihood Diversification i n Developing Countries. Journal of Agricultural Economics, 51(2), 289-302.

[3]. Lanjouw, J.O and Lanjouw, P. (2001). The rural non-farm sector issues and evidence. Agricultural Economics, 26(1), 1-23

[4]. Haggblade, S., Hazell, P., \& Reardon, T. (2010). The Rural Non-farm Economy: Prospects for Growth and Poverty Reduction. World Development, 38(10), 1429-1441.

[5]. Rijkers, B., \& Costa, R. (2012). Gender and Rural Non-Farm Entrepreneurship. World Development, 40(12), 2411-2426

[6]. Barret, C.B., Reardon, Thomas, Webb, P. (2001). Nonfarm Income Diversification and Household Livelihood Strategies in Rural Africa: Concepts, Dynamics, and Policy Implications Christopher B. Barrett. Food Policy, 26, 315-331.

[7]. Deininger, K., \& Olinto, P. (2001). Rural Nonfarm Employment and Income Diversification in Colombia. World Development, 29(3), 455-465.

[8]. Owusu, V., Abdulai, A., \& Abdul-rahman, S. (2011). Non-farm work and food security among farm households in Northern Ghana. Food Policy, 36(2), 108-118

[9]. Rosenbaum, P.R., and D.B. Rubin (1983). The Central Role of the Propensity Score in Observational Studies for Causal Effects. Biometrika, vol. 70(1): 41-55

[10]. Reardon, T. (1997). Using evidence of household income to inform study of the rural non-farm labour market in Africa. World Development, vol. 25(5) 735-747.

[11]. Debalen A.S. Paternostro and Pirre G. 2004). The returns to participation in the non-farm sector in rural Ruwanda. World Bankresearch working paper.

[12]. Ali, M., \& Peerlings, J. (2012). Farm households and nonfarm activities in Ethiopia: does clustering influence entry and exit? Agricultural Economics, 43, 253-266.

[13]. Sianesi, B. (2004). Evaluation of the active labor market programs in Sweden. The Review of Economics and Statistics Vol. 86, pp. 133-155.

[14]. Becker, S. O., \& Ichino, A. (2002). Estimation of Average Treatment Effects based on propensity scores. The Stata Journal, 2(4), $358-377$.

[15]. NBS (2010). Nigerian General Household Survey: Basic Information Document, Abuja Nigeria. Available www.nigerianstat.gov.ng 